\title{
分布写像に基づくガウス性情報源の効率的符号化
}

\section{Efficient Gaussian Source Coding Based on Distribution Mapping}

\author{
正会員 高 村 誠 之 $之^{\dagger}$, 正会員 八 島由 幸
}

Seishi Takamura ${ }^{\dagger}$ and Yoshiyuki Yashima ${ }^{\dagger}$

\begin{abstract}
Gaussian sources are commonly found in the fields of mathematics and engineering. There is instantaneous code for geometric and two-sided geometric distributions; however, there is no simple, instantaneous code for normal distributions. Therefore, we have developed a method of mapping a normal distribution onto a geometric distribution before applying Golomb codes. Experimental results showed that our method consistently yielded coding efficiency of more than $98 \%$ for quantized Gaussian sources, which is comparable to the coding efficiency of second-order Huffman codes. For actual video coding residual signals, our codes were more efficient by six points than straightforward Golomb codes. Furthermore, we developed and demonstrated an accurate estimation method for determining optimal Golomb parameters, and we investigated the use of hybrid coding to enhance the coding performance.
\end{abstract}

キーワード : 情報源符号化, ガウス性信号源, Golomb 符岇, Huffman 符岇, 指数分布

\section{1. まえ がき}

生起確率が正規分布に従うガウス性信号 (以後離散・零平 均とする) は埋学・工学の様々な場面で現れる極めて重要な 信号である.

整数信号の符号化方式は多数知られているが，うち Golomb 符号 ${ }^{1)}$ は，指数分布に従う信号を最も高効率に符 号化でき，符号化・復号いずれにも符号表が不要で，処理 が極めて簡易であり，さらに任意に大きな整数入力值を符 号化できるという特長があり，広く用いられている。しか しながらガウス性信号に対しては，符号化効率が低下して しまうという問題があった。

Golomb 符号のように符号表を必要としない符号には, Fibonacci 符号, Elias 符号, Exp-Golomb 符号など様々存 在するが，信号の生起確率が正規分布に従うことを仮定し た符号は存在しない2)。例えば，MPEG-4 AVC ${ }^{3)}$ で用いられ ているExp-Golomb 符号は, 指数分布およびこれよりも急 峻な分布に向いた符号である. Xue ら ${ }^{4)}$ の Hybrid Golomb 符号は, 構成が複雑であり, かつ一般化正規分布のうち指 数分布よりも急峻な分布が対象であるため, 緩やかな分布 であるガウス性信号に対しては効率が低下する。また Mal$\operatorname{var}^{5)}$ の一般化正規分布の学習型連長/Golomb 符号は, 正規 分布に対する效率が Golomb 符号よりも劣る。これらは,

\footnotetext{
2006 年 12 月 12 日, 冬季大会で発表

2007 年 2 月 23 日受付, 2007 年 6 月 19 日再受付, 2007 年 7 月 11 日採録

†日本電信電話株式会社 NTT サイバースペース研究所

（テ239-0847 横須賀市光の丘 1-1 Y-517A, TEL 046-859-2371）

$\dagger$ NTT Cyber Space Laboratories, NTT Corporation

(Y-517A, 1-1 Hikarino-oka, Yokosuka, Kanagawa, 239-0847 Japan)
}

Golomb 符号が想定している信号生起確率が，正規分布で はなく指数分布に一致していることに起因する，本質的な 問題である。

Huffman 符号は可変長符号中最も効率が高く，算術符号 は定常的信号源を理論効率限界まで圧縮可能な符号である が，いずれも符号表あるいは牛起頻度表の伝送と，より多 量の計算量が必要である.

従来ガウス性信号源の符号化において「処理の簡易さ」 を優先する場合，効率を犠牲にし Golomb 符号化されてい た ${ }^{2)}$. 本論文では，ガウス性信号源を指数分布に可逆写像 する方法を提案しの，これを実際のガウス性信号源に施し た後に Golomb 符号化することで，符号化効率が改善され ることを示す。

\section{Golomb 符号の基本的性質}

Golomb 符号は，1 以上の整数值をとる Golomb パラメー

表 1 自然数 $z=0 \ldots 10$ に対する Golomb 符号表の例. $m=1 \ldots 6$ は Golomb パラメータ

Example of Golomb codes for input integers of $z=0$ to 10 with Golomb parameters of $m=1$ to 6 .

\begin{tabular}{r|llllll}
\hline \hline$z$ & $m=1$ & $m=2$ & $m=3$ & $m=4$ & $m=5$ & $m=6$ \\
\hline 0 & 0 & 00 & 00 & 000 & 000 & 000 \\
1 & 10 & 01 & 010 & 001 & 001 & 001 \\
2 & 110 & 100 & 011 & 010 & 010 & 0100 \\
3 & 1110 & 101 & 100 & 011 & 0110 & 0101 \\
4 & 11110 & 1100 & 1010 & 1000 & 0111 & 0110 \\
5 & 111110 & 1101 & 1011 & 1001 & 1000 & 0111 \\
6 & 1111110 & 11100 & 1100 & 1010 & 1001 & 1000 \\
7 & 11111110 & 11101 & 11010 & 1011 & 1010 & 1001 \\
8 & 111111110 & 111100 & 11011 & 11000 & 10110 & 10100 \\
9 & 1111111110 & 111101 & 11100 & 11001 & 10111 & 10101 \\
10 & 11111111110 & 1111100 & 111010 & 11010 & 11000 & 10110 \\
\hline
\end{tabular}

(95) 1357 
夕 $(m$ と呼ぶことにする $)$ にり, その符号表現が変化す る. 表 1 は, 自然数 $z=0 \ldots 10$ に対する Golomb パラメー 夕 $m=1 . . .6$ における Golomb 符号である. $m$ が増すにつ れ符号長の增加は緩やかになるため緩やかな分布の符号化 に向き, 逆に $m$ が減少するにつれ符号長の増加は急になる ため 0 に集中する急峻な分布の符号化に向く.

指数分布に従う信号としては，画像信号中，時空間的に 隣接する画素間の輝度差や，画素輝度值の直交変換係数な どがあり, 例えば, 静止画可逆・準可逆符号化方式である JPEG-LS ${ }^{7)}$ も予測誤差信号の符号化に Golomb 符号を用い ている.

表 1 からわかるように, Golomb 符号には被符号化整数 $z$ の值が $m$ 増すと符号長が 1 ビット増す (生起確率が $1 / 2$ に なることに等価), という性質がある. したがって, $z$ の生 起確率において

$$
\begin{aligned}
\operatorname{Prob}(z) & \propto 2^{-z / m} \\
& =\exp (-\log 2 \cdot z / m)
\end{aligned}
$$

という関係が成り立つ場合, パラメータ $m$ の Golomb 符号 が最適符号となる。

\section{3. 提 案手法}

\section{1 可逆正規-指数分布写像}

本写像では, 整数入力信号を 2 要素ずつの対 $(x, y)$ と見 做し, これに一意の番号付けを施した結果として, 0 以上 の整数值 $z(x, y)$ を得る. $z$ が満たすべき条件は

$$
\begin{aligned}
\min _{x, y} z(x, y) & =0 \\
l(x, y)<l(a, b) & \Longrightarrow z(x, y)<z(a, b) \\
z(x, y)=z(a, b) & \Longleftrightarrow(x, y)=(a, b)
\end{aligned}
$$

である.ここで $l(x, y)$ は原点と点 $(x, y)$ の距離を求める関 数で, 例えば, ユークリッド距離

$$
l(x, y)=\sqrt{x^{2}+y^{2}}
$$

を用いる．原点からの距離が等しい格子点は一般に複数存 在するが, それらの $z$ 值への対応付けは任意である. 図 1 は, 反時計回りを保つ対心例である。この写像は明らかに 可逆である.

また距離関数としてユークリッド距離 (6) 式の代わりに 平方根を含まない

$$
l(x, y)=x^{2}+y^{2}
$$

を用いても写像結果は不変である.

\section{2 分布写像に関する考察}

まず格子点 $(x, y)$ の $z$ 值は, 半径 $\sqrt{x^{2}+y^{2}}$ の円周内の格 子点数にほぼ等しく, それは円の面積にほほ等しい。した がって

$$
z \approx \pi\left(x^{2}+y^{2}\right)
$$
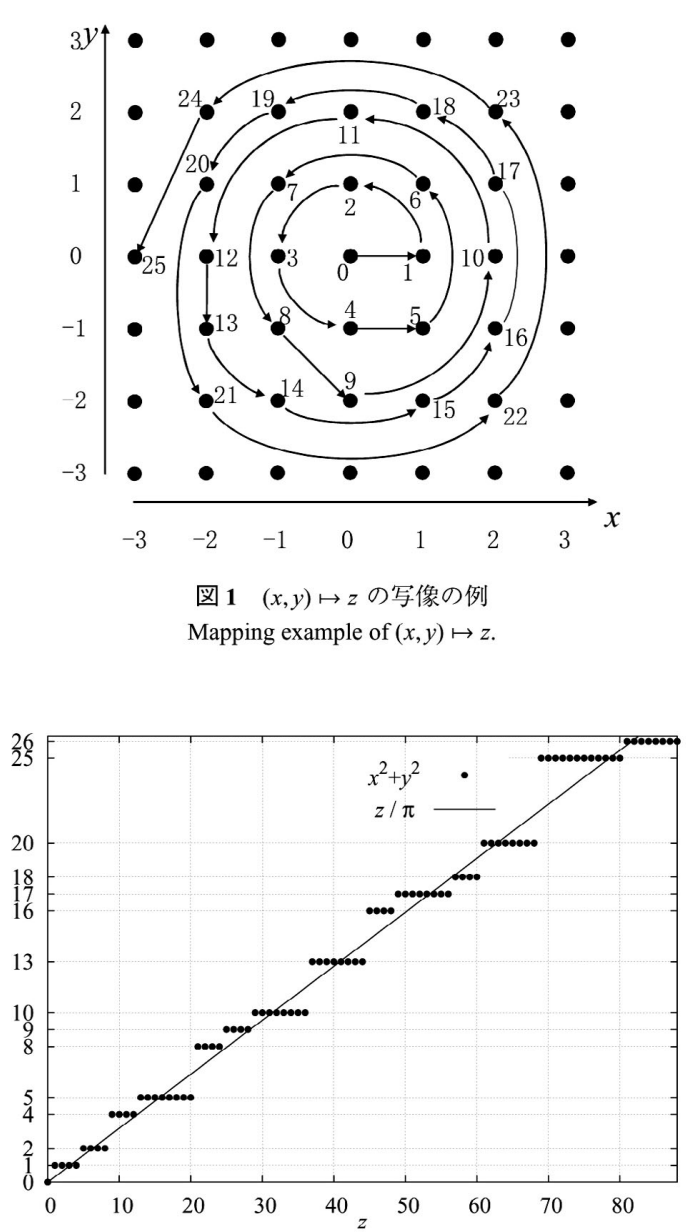

(a)

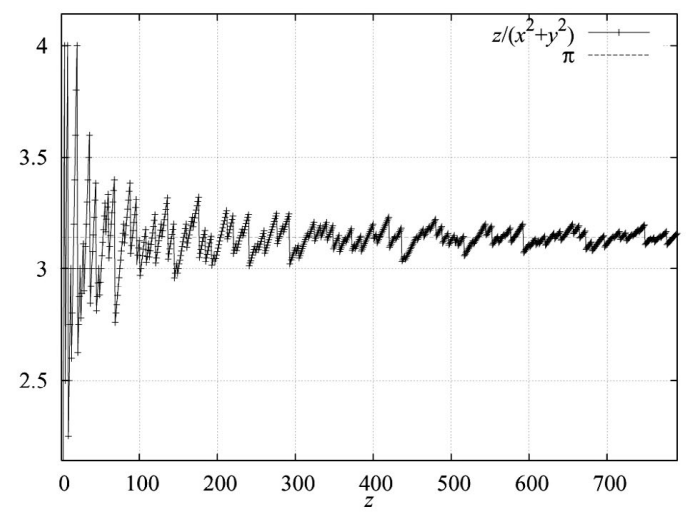

(b)

図 $2(x, y)$ と $z$ の関係. (a) $x^{2}+y^{2}$ と $z / \pi$, (b) 両者の比 $z /\left(x^{2}+y^{2}\right)$ The relation between $(x, y)$ and $z$. (a) $x^{2}+y^{2}$ and $z / \pi$, (b) their ratio $z /\left(x^{2}+y^{2}\right)$.

となる. 図 2(a)に，(6) 式に基づく写像における $(x, y)$ と $z$ の関係を四示する. 同図 (b) は両者の比であり, $z$ が増加す るに従い比が $\pi$ に漸近している様子が観察でき，大局的に (8) 式の関係が成り立っていることがわかる.

$x$ が(および $y$ も独立に) 正規分布 $N\left(0, \sigma^{2}\right)$ に従うものと する. i.i.d. 対である $(x, y)$ は 2 次元正規分布に従い, さら に(8) 式を用いると

$$
\operatorname{Prob}(x, y)=\frac{1}{2 \pi \sigma^{2}} \exp \left(-\frac{x^{2}+y^{2}}{2 \sigma^{2}}\right)
$$




$$
\approx \frac{1}{2 \pi \sigma^{2}} \exp \left(-\frac{z}{2 \pi \sigma^{2}}\right)
$$

を得る。

(10) 式は $z$ に関する指数分布に他ならない. したがって, Golomb 符号による効率的な符号化が期待できる.

\section{3 最適 Golomb パラメータの推定}

分散 $\sigma_{e}^{2}$ の指数分布

$$
\operatorname{Prob}(z)=\frac{1}{\sigma_{e}} \exp \left(-\frac{z}{\sigma_{e}}\right)
$$

と (10) 式とを比較し

$$
\sigma_{e}=2 \pi \sigma^{2}
$$

を得る。

(11) 式に従う分布の符号化効率を最も高めると期待され る Golomb パラメータ $m_{\mathrm{est}}$ は, (2) 式と (11) 式を比較し得 られる

$$
-\log 2 / m=-1 / \sigma_{e}
$$

を満たす $m$ に等しいので，(12)式より

$$
m_{\mathrm{est}}=2 \log 2 \cdot \pi \sigma^{2}
$$

が得られる。

この推定の良否は, 4.3 節において計算機実験により確 認する.

\section{4 ガウス性信号源符号化アルゴリズム}

我々が提案するガウス性信号源の符号化アルゴリズムは 以下のようになる。

（1） 入力される信号を逐次 2 個ずつまとめ $(x, y)$ とする

(2) $(x, y)$ を 3.1 節の方法で自然数 $z$ に写像する

(3) $x$ の分散に従い適切な Golomb パラメー夕 $m_{\mathrm{est}}$ を 3.3 節の方法で求めこれに基づき $z$ を Golomb 符号 化する，あるいは符号化効率を最大化するパラメー 夕 $m_{\mathrm{opt}}$ により $z$ を Golomb 符号化する

以降 $m_{\mathrm{opt}}$ は複数回の符号化試行の結果得られた「最良な」 パラメータを指すものとする。

\section{4. 計算機シミュレーション}

符号化評価用信号源として, 現実世界にて観測された実 際のガウス性信号および理想的なガウス性信号のそれぞれ について，提案方式の符号化効率を検証した.

提案手法は 2 入力を 1 信号に写像しているが，これは情 報源の 2 次拡大を行っていることに相当する.そこで符号 化効率の比較検証においては,

- 提案手法,

・情報源拡大を行わない場合の Huffman 符号,

- 情報源拡大を行わない場合の Golomb 符号 ${ }^{2)}$, そして

- 情報源の 2 次拡大を行った場合の Huffman 符号 (可変 長符号における効率上限を与える)
表 2 ビデオ符号化パラメータとその残差信号特徵諸量. QP 值 はベースレイヤのもの. m.e. は平均零次エントロピー (bit). Video coding settings and characteristics of the residual signal. QP values are of the base layer. m.e. stands for the mean (zeroth-order) entropy in bits.

\begin{tabular}{l|cl|clll}
\hline \hline & \multicolumn{2}{|c|}{ GOP 構造 } & \multicolumn{1}{c|}{ QP 值 } & 平均*100 分散 & 尖度 & m.e. \\
\hline data1 & III... & I:22 & -1.17 & 1.58 & 3.08 & 2.37 \\
data2 & III... & I:12 & -1.15 & 0.317 & 3.39 & 1.22 \\
data3 & IPP... & I:17, P:10 & -1.40 & 0.250 & 4.20 & 1.06 \\
data4 & IPP... & I:17, P:20 & -1.66 & 1.19 & 3.04 & 2.17 \\
data5 & IBP... & I:17, P:15, B:11 & -1.72 & 0.446 & 3.07 & 1.46 \\
data6 & IBP... & I:17, P:15, B:19 & -2.66 & 0.760 & 3.80 & 1.83 \\
\hline
\end{tabular}

の四手法の効率を比較した.

特に断らない限り Golomb 符号化においては符号化効率 を最大化する Golomb パラメータ， $m_{\mathrm{opt}}$ を用いるものとす る.ここで，符号化効率は次のように定義する:

符号化効率 $=\frac{\text { 零次エントロピー }}{\text { 米均符号長 }} \times 100(\%)$

\section{1 実際の信号源に対する符号化性能}

まず工学的現場で実際に発生した信号源 (ビデオ信号を 符号化復号し重畳する符号化雑音) について, 提案手法の 符号化性能の評価を行った。

符号化映像は CITY 4CIF 60Hz であり, MPEG-4 AVC のスケーラブル拡張方式の参照ソフトウェア $\mathrm{JSVM}^{8)}$ によ り, $\mathrm{RD}$ 最適化 $\mathrm{ON}$ ，ピクチャタイプ毎 $\mathrm{QP}$ 固定, FGS 機能 による一段階 SNR エンハンス符号化を行った。得られた 6 種のデータの特徵量は表 2 に示す通りである。サンプル数 は 1,700 万点から 3,000 万点の間であった. エンハンスメ ントレイヤの QP 值は, 表に示した QP 值より6小さな值 に相当する。データを取得したピクチャタイプは, III 構造 では I のみ, IPP 構造では P のみ, IBP 構造では B のみで あり, ベースレイヤにて $8 \times 8$ 変換が選ばれたブロックに おいて，エンハンスメント後の復号信号と原画像との輝度 差分信号を実験データとした。

信号源 data1 の分布を図 3(a) に示す. 縦軸は対数確率で, 明らかな放物線形状がみてとれる (正規分布も縦対数グラフ では放物線となる). 実際表 2 によれば data1 の尖度は 3.08 であり，正規分布の尖度 3 に近い(分布が急峻になるほど 尖度が人きくなり，例えば，指数分布の尖度は 6 である).

この信号を入力順に二つずつ対とした場合の分布を図 3(b) に示す．明らかな回転放物面をなしていることが，グラフ 形状からも等官線 (グラフ下部) からもうかがえる.

さらにこの信号に対し，提案の分布写像を施した結果の 分布グラフを四 3(c) に示す. また $m=6,7,8$ における (2) 式のグラフ (正規化後) も重畳した. 本写像により, 図 3(a) で放物線状であった分布が Golomb 符号向きの直線的な分 布に変換できていることがわかる.

提案手法および比較三手法による符号化効率を表 3 に示 す. 同表には $m_{\mathrm{opt}}$ も記した. 2 次拡大 Huffman 符号は常に 98\%を超える最も高い符号化效率を与えており，提案手法 はそれに次ぐ効率となっている。平均エントロピーがそれ ぞれ 1.22 および 1.06 と低いdata 2 および 3 については，情 


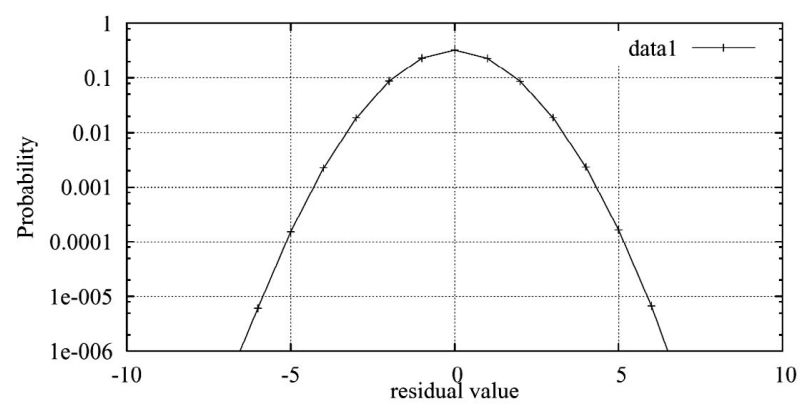

(a)

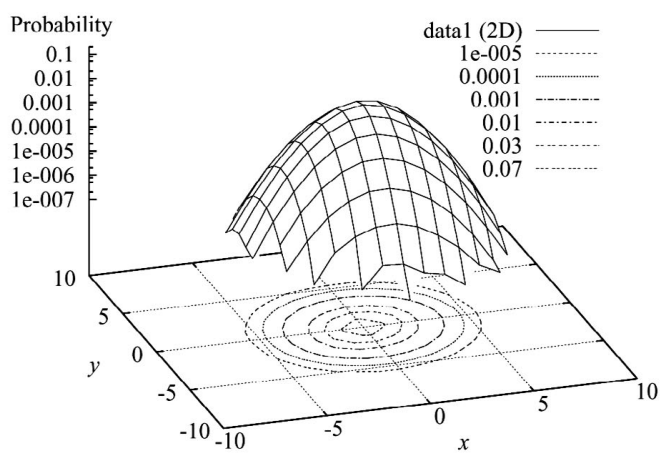

(b)

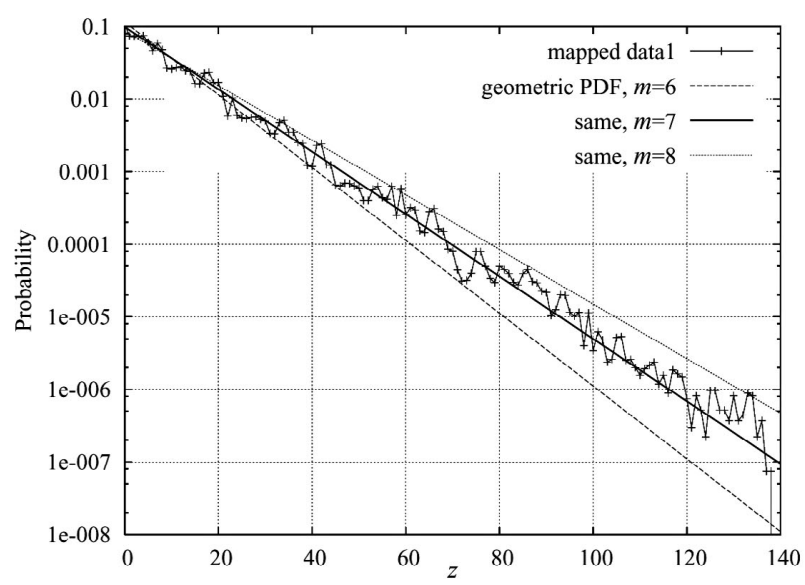

(c)

図 3 ビデオ符号化残差信号の分布. 縦軸は全て対数確率. (a) 個別分布 (1 次元), (b) 人力順に対とした場合の分布 (2 次 元), (c) 写像後分布および指数分布グラフ

Actual video coding residual data distribution. Vertical scales, which mean probability, are all in log-scale. (a) singular data distribution (1dimensional), (b) coupled data distribution (2-dimensional), (c) distribution after distribution mapping, and some geometric PDFs.

報源を拡大しない場合，符号長が $1 \mathrm{bit} / \mathrm{symbol}$ 以上の制約 のある可変長符号化の効率低下が観察される. 提案手法の 符号化効率は最低でも約 90\%を達成しており, 平均では提 案手法が $94.86 \%$, Golomb 符号は $88.65 \%$ と約 6 ポイント の差があった. data1 については図 3(c) で視覚的に明らか であったように, Golombパラメータとして $m=7$ が最適
表 3 ビデオ符号化残差信号に対する符号化効率 $(\%)$ および $m_{\mathrm{opt}}$ Coding efficiency (in percentage) for video coding residual data sets and $m_{\text {opt }}$ values.

\begin{tabular}{c|ccccc}
\hline \hline 情報源 & 提案手法 & Golomb & $\begin{array}{c}\text { 2 次桩大 } \\
\text { Huffman }\end{array}$ & Huffman & $m_{\mathrm{opt}}$ \\
\hline data1 & 99.27 & 93.00 & 99.39 & 97.90 & 7 \\
data2 & 89.32 & 82.90 & 98.33 & 83.04 & 2 \\
data3 & 90.16 & 76.96 & 98.42 & 77.20 & 1 \\
data4 & 98.46 & 94.47 & 99.16 & 95.71 & 6 \\
data5 & 94.69 & 89.24 & 98.25 & 89.57 & 2 \\
data6 & 97.27 & 95.32 & 99.05 & 95.85 & 3 \\
\hline 平均 & 94.86 & 88.65 & 98.77 & 89.88 & - \\
\hline
\end{tabular}

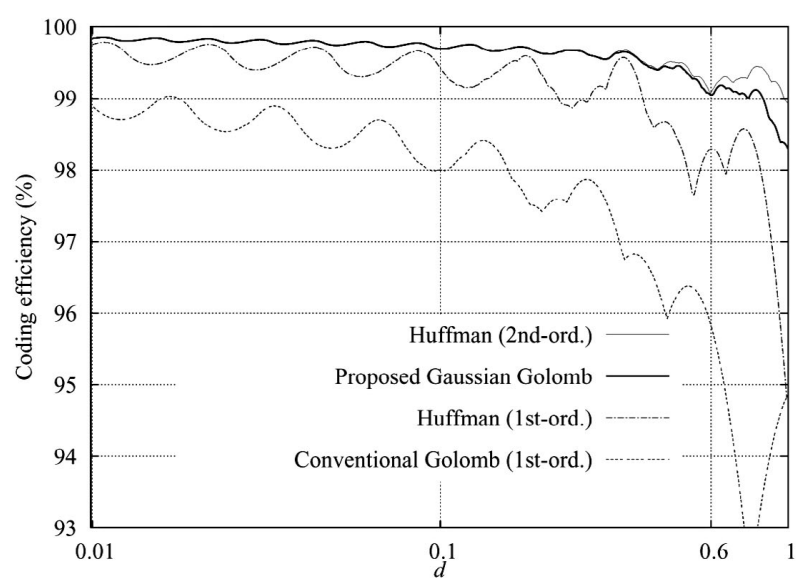

図 4 量子化ガウス性信号に対する符号化効率 Coding efficiency comparison for quantized Gaussian sources.

である。

\section{2 量子化ガウス性信号に対する符号化性能}

Malvar は提案符号 (学習型連長/Golomb 符号) の検訨用 に，一般化正規分布を数值計算により量子化した信号を用 いている ${ }^{5}$. 本論文でも検証用信号源の一つとして, 量子 化正規分布を用いることとする。すなわち分散 1 の正規分 布をステップサイズ $d$ で量子化し，各 bin に中心を 0 とす る量子化值 $(\ldots,-2,-1,0,1,2, \ldots)$ を割り振る.

様々な $d$ に対する量子化ガウス信号の符号化結果を図 4 に 示す. 2 次拡大 Huffman 符号が当然ながら最も高効率であ り, 次いで提案手法, 拡大なしの Huffman 符号, Golomb 符 号の順となっている. 提案手法の符号化効率は常に $98.3 \%$ 以 上であり, 特に $d<0.6$ の領域では 2 次拡大 Huffman 符号 とほぼ等しい 99\%以上の効率を与えている.

\section{3 量子化ガウス性信号源における $m_{\mathrm{est}}$ の最適性評価} 信号源の分散 $\sigma^{2}$ と $d$ の間には

$$
\sigma^{2}=1 / d^{2}+1 / 12
$$

という関係があるので, (14) 式は

$$
m_{\mathrm{est}}=2 \log 2 \cdot \pi\left(1 / d^{2}+1 / 12\right)
$$

とも表せる。

(17) 式の関係を用いることで，符号化効率を高めると 思われる Golomb パラメータ $m_{\text {est }}$ が求められる.ただ これは理論式であるので，実際に符号化効率を最高にする Golomb パラメータ $m_{\mathrm{opt}}$ とは必ずしも一致しない.この理 


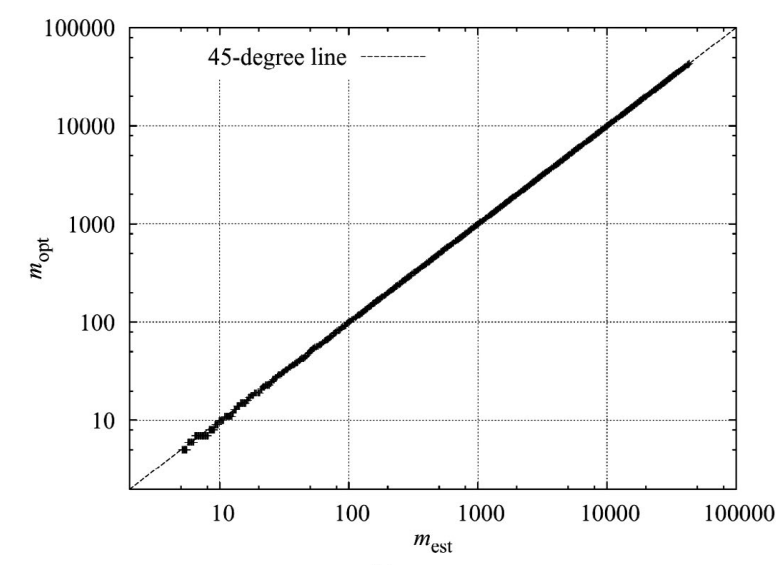

(a)

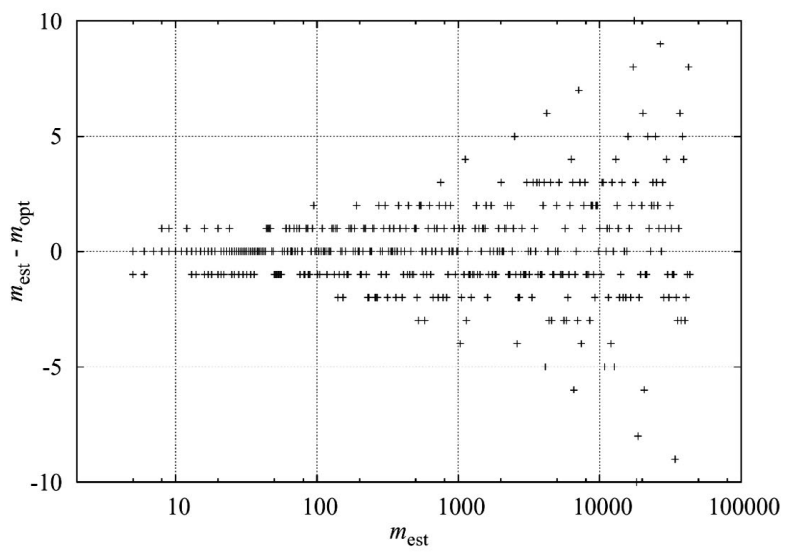

(b)

図 $5 m_{\mathrm{opt}}$ の推定䛊差. (a) 様々な $d$ に対応する量子化ガウス性 信号の $m_{\mathrm{est}}$ および尖際に符号化し得られた $m_{\mathrm{opt}}$, (b) $m_{\mathrm{est}}$ の推定誤差

Estimation of $m_{\text {opt }}$. (a) estimated $m_{\text {est }}$ for a given quantized Gaussian source and actual $m_{\mathrm{opt}}$, (b) estimation error of $m_{\mathrm{est}}$.

由としては, Golomb パラメータは疎な離散值 (整数值)し かとらないが実際の分布の分散は連続值となること, また, $m=2^{q}$ ( $q$ は自然数) の場合の Golomb 符号 (いわゆる Rice 符号) は, $m \neq 2^{q}$ の場合の Golomb 符号よりも符号化効率 がわずかに高いことなどが考えられる.

まず定性的に， $m_{\mathrm{est}}$ が $m_{\mathrm{opt}}$ のどの程度良い推定になって いるかを確認するために，量子化ガウス性信号について雨 者の関係を調べた結果を図 5 に示す，図から明らかなよう に，両者の值が互いに極めて近いことがわかる。

より定量的に, Golomb パラメータとして $m_{\mathrm{est}}$ と $m_{\mathrm{opt}}$ を 用いた場合の符号化効率をそれぞれ求めた。結果を図 6 に 示す. $m_{\mathrm{est}}$ が充分に良好な推定であることが明白に観察さ れる。

\section{4 ハイブリッド符号による効率改善}

図 4 を見ると，比較的大きな $d(>0.6)$ の值において(すな わち分布がより急峻な場合), 提案方式と 2 次拡大 Huffman 符号との性能差が大きい.この理由としては，(8) 式は近似 であり一般に成り立たって扔らず，(特に生起確率が高く符 号化効率に大きな影響を及ぼす) $z$ 值が小さな領域に扔いて, 図 2(b) に示されるように $z$ の理論值からの乘離が相対的に

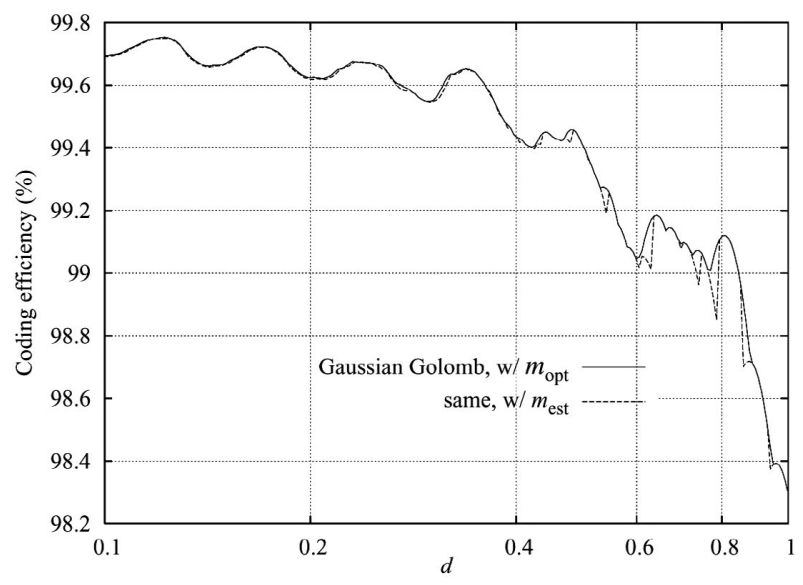

図 6 Golomb パラメータの推定值および最適值に㧍ける符号化 効率比較. 実線は図 40 それと同一である. $d$ が小さい 領域 $(d<0.1)$ は両者に違いが殆ど見られないため省略 Coding efficiency comparison for estimated and optimal Golomb parameters. The solid line is the same as the solid line in Fig. 4. Small $d$ area (i.e., $d<0.1$ ) is omitted since two graphs are almost identical.

大きいことから，被符号化整数に対し対数確率が線形であ ることを前提としている Golomb 符号は効率が低下してし まうことが考えられる．図2の分布は解析的モデルにより 表現することが困難であるため, Merhav らの最適符号化設 計 9)ような解析的アプローチで対処することが難しい.

この問題に対する一つの簡易改善策として, $|x|,|y| \leqq H$ の領域 (図 7 の黑格子点) については 2 次拡大 Huffman 符 号化を施し，残りの部分 ('OB' と呼ぶことにする)につい ては

- $\mathrm{OB}$ 符号,

・領域符号 (2 ビット),

・後述の写像で得られる值 $z$ に対応する Golomb 符号 を結合した符号により符号化することを試みた。ここで Huffman 符号表の設計に扔いて OB 領域全体の生起確率和 も考慮しつつ $\mathrm{OB}$ 符号を得ておくことに注意する．符号表 作成不要という元々の提案手法の利点は薄れるが, $H$ の值 をできるだけ小さな值とすることで符号表作成はできる限 り小規模に抑えることとした。

いくつかの写像例を図 7 中に付記した．距離関数を定式 化すると次のようになる:

$$
l(x, y)=\max (|x|,|y|)+\frac{\min (|x|,|y|)}{\max (|x|,|y|)+1}
$$

領域 $\mathrm{A}$ を例にとると, 正写像 $(x, y) \mapsto z$ は次のように なる:

$$
\begin{aligned}
z & =n_{x-H-1}+2|y|+\left\{\begin{array}{rr}
0 & (y>0) \\
1 & (y \leqq 0)
\end{array}\right. \\
\text { ただし } n_{k} & =k^{2}+(2 H+1) k-1
\end{aligned}
$$

逆写像 $z \mapsto(x, y)$ は次のようである:

$$
\begin{aligned}
& x=k_{z}+H \\
& y=(-1)^{z+1}\left\lfloor\frac{z-n_{k-1}}{2}\right\rfloor
\end{aligned}
$$




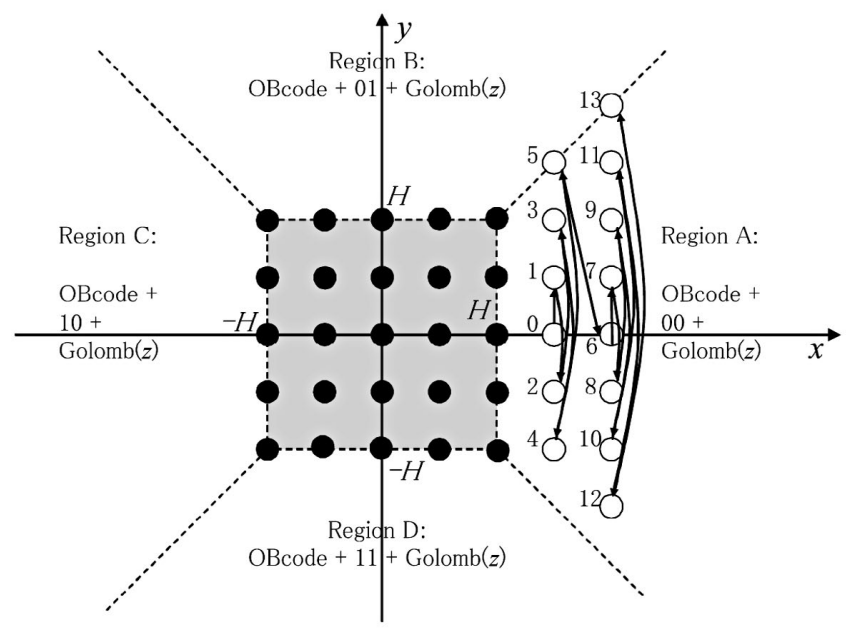

図 7 ハイブリッド Huffman/Golomb 符号化 $(H=2)$ の模式図. 領域 A における最初のいくつかの $z$ 值も付記した

Hybrid Huffman/Golomb coding $(H=2)$. Some of the first $z$ values in Region $\mathrm{A}$ are embedded.

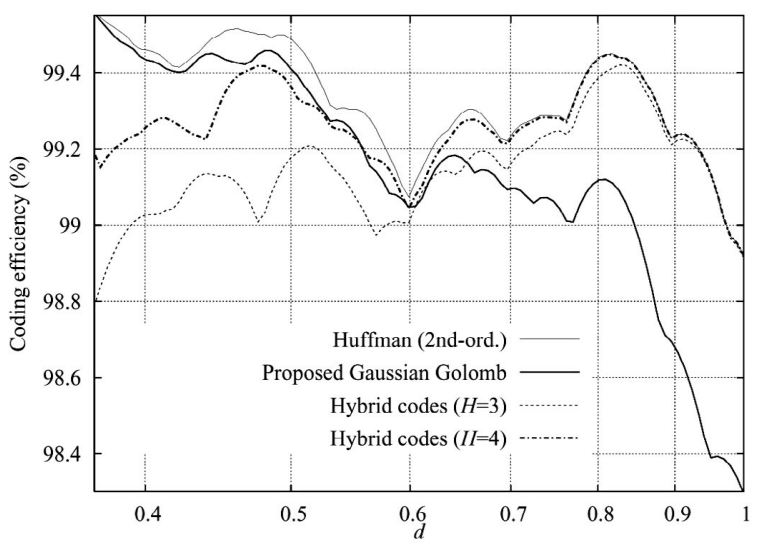

図 8 ハイブリッド符号の符号化効率 Coding efficiency of hybrid codes.

となる．ここで $k_{z}$ は, $k$ に関する 2 次方程式 $n_{k}=z$ の正の 解に基づき

$$
k_{z}=\left\lceil\frac{-(2 H+1)+\sqrt{(2 H+1)^{2}+4(z+1)}}{2}\right\rceil
$$

として与えられる。このように，この写像は正方向・逆方 向ともに解析的であり $o(1)$ のオーダで計算ができる. 図 1 のような円周状の写像ではないが, 2 次元 $\mapsto 1$ 次元の写像 ではあるため，やはりガウス分布を定性的に指数分布に変 換することができる.

$H=3$ 㧍よび 4 の場合のハイブリッド符号の符号化効率 を, 2 次拡大 Huffman 符号および元々の提案手法と比較し たものを図 8 に示す. $d>0.6$ において $H=4$ のハイブ リッド符号の性能は大きく改善し 2 次拡大 Huffman 符号と 殆ど遜色のない効率が得られていることがわかる。この結 果より, $\left((2 H+1)^{2}+\left.1\right|_{H=4}=\right) 82$ 個の符号語の作成を許せ ば, $d>0.6 つ ま り(16)$ 式により分散が 2.86 未満ではこの ハイブリッド符号が効果的であるといえる。

\section{5. むす び}

本論文では，正規分布を指数分布に可逆写像を施す新手 法を提案し，Golomb 符号と組合せることで，従来簡易に 高効率符号化ができなかったガウス性信号を, 符号表の伝 送や生成をせずに高効率に符号化できることを示した。さ らに, 最適な Golomb パラメー夕を求める方法についても 考察し，符号化実験を通し推定でも充分に良い效率を与え ることを示した．また，特に分散が小さく急峻な分布を符 号化する際の性能低下は, 部分的に 2 次拡大 Huffman 符号 を用いることにより緩和できることも示した。

$(x, y) \mapsto z$ の対応付けは計算機プログラムにより簡易に 生成可能であるし， $x$ および $y$ の最大值がわかっていれば 予め対応表を作り記憶しておいてもよい. 送受信側で写像 $z(x, y)$ を定義しておけば無論この表は伝送不要である.

\section{〔文献〕}

1) S. W. Golomb: "Run-length encodings", IEEE Trans. Inf. Theory, 12, 3, pp. 399 401 (July 1966)

2) P. Boldi and S. Vigna: "Compressed perfect embedded skip lists for quick invertedindex lookups", Proc. SPIRE 2005, 3772, pp. 25-28 (2005)

3) ISO/IEC 14496-10:2003 "Information technology - Coding of audio-visual objects - Part 10: Advanced Video Coding”, (2003)

4) S. Xue, Y. Xu and B. Oelmann: "Hybrid Golomb codes for a group of quantised GG sources", IEE Proc. Vis. Image Signal Process., 150, 4, pp. 256-260 (Aug. 2003)

5) H. S. Malvar: "Adaptive run-length / Golomb-Rice encoding of quantized generalized gaussian sources with unknown statistics", Proc. Data Comp. Conf. (DCC 2006), pp. 23-32 (2006)

6）高村, 八島: “ガウス情報源の最適符号”, 2006 年映情報学冬季大, 1-11 (Dec. 2006)

7) ISO/IEC 14495 "Information technology - Lossless and near-lossless compression of continuous-tone still images, Part 1: Baseline" (1999)

8) ITU-T and ISO/IEC JTC 1, "JSVM 4 software", JVT-Q203 (Oct. 2005)

9) N. Merhav, G. Seroussi and M. J. Weinberger."'Optimal prefix codes for sources with two-sided geometric distributions”, IEEE Trans. Inf. Theory, 46, 1, pp. 121135 (Jan. 2000)

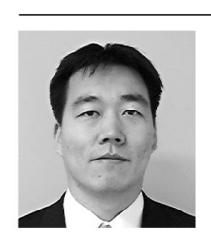

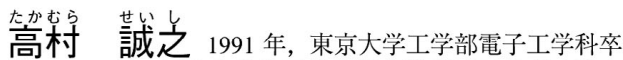
業. 1996 年, 同大大学院工学系研究科電子工学専攻博士 課程修了. 同年, 日本電信電話 (株) 入社. 以来, 画像 · 映像の高能率圧縮符号化アルゴリズムの研究開発, MPEG 国際標準化活動などに従事. 現在, 日本電信電話 (株)NTT サイバースペース研究所画像メディア通信プロジェクト 映像符号化技術グループ主任研究員. 2005 年〜2006 年 スタンフォード大学客員研究員. 博士 (工学). 正会員.

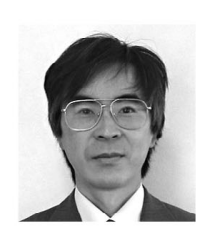

分島 届幸 1981 年, 名古屋大学工学部電子工学科 卒業. 1983 年, 同大大学院工学研究科電子工学専攻修士 課程修了．同年，日本電信電話公社 (現 NTT) 人社. 以来, 主として画像信号の高能率符号化アルゴリズム, HDTV 信号符号化装置, 動画像信号処理, MPEG 関連システムの 研究開発に従事. 現在, 日本電信電話 (株)NTT サイバー スペース研究所画像メディア通信プロジエクト咉像符号 化技術グループリーダ，主幹研究員．2004 年より東京工 業大学客員教授. 博士 (工学). 正会員. 